\title{
GAMBARAN PENGETAHUAN TENTANG MEROKOK PADA ORANG TUA YANG MEMILIKI ANAK PEROKOK USIA 10-15 TAHUN DI DUSUN MODINAN BANYURADEN GAMPING SLEMAN
}

\author{
Nurmala Wulandari ${ }^{1}$, Ni Ketut Mendri ${ }^{2}$, Eko Suryani ${ }^{3}$ \\ ${ }^{1)}$ Nurmala.wulandr@gmail.com Mahasiswa Jurusan Keperawatan Poltekkes Kemenkes \\ Yogyakarta Jl. Tata Bumi No. 3, ${ }^{2,3}$ Dosen Jurusan Keperawatan Poltekkes Kemenkes Yogyakarta
}

\begin{abstract}
ABSTRACK
Based on Research (RisKesDa) on years 2013 Yogyakarta Special Region is a province with a prevalence of age $\geq 10$ years each day smoking as much as $21.2 \%$. There are many reasons teenagers or children age $\leq 15$ years of smoking. The factor that causes the child to smoke are from the environment of smoking parents or peers and from the individual himself. This study was conducted to find out the description of parent's knowledge about cigarettes in parents own children smokers age 10-15 years in the Village Modinan. This research is a descriptive study using survey method. The sample was 38 respondents by using Purposive Sampling technique. Measuring tools using questionnaire. Parent's knowledge level on cigarettes in parents own had 10-15 year old smokers in 38 respondents showed that knowledge level was in good category. Obtained $60.5 \%$ of parents at the age of 36-45 years, $63.2 \%$ of parents have senior high school, $52.6 \%$ of parents work as housewife, and 55.4\% of unemployed parrent. Knowledge of cigarettes in parents own have 10-15 year old smokers in Modinan Village mayority in the category of good knowledge.
\end{abstract}

Keywords : Knowledge, Parents, Cigarettes

\begin{abstract}
ABSTRAK
Berdasarkan Riset Kesehatan Dasar (RisKesDa) tahun 2013 Daerah Istimewa Yogyakarta merupakan provinsi dengan prevalensi umur $\geq 10$ tahun yang tiap hari merokok sebanyak $21,2 \%$. Ada banyak alasan para remaja atau anak usia $\leq 15$ tahun berperilaku merokok. Faktor-faktor yang mengakibatkan anak merokok adalah faktor dari lingkungan yaitu orang tua yang merokok atau teman sebayanya dan faktor dari individu sendiri. Penelitian ini dilakukan untuk mengetahui gambaran pengetahuan orang tua tentang rokok pada orang tua yang memiliki anak perokok usia 10-15 tahun di Dusun Modinan. Penelitian ini merupakan penelitian dekskriptif dengan menggunakan metode survey. Sampel berjumlah 38 responden dengan menggunakan teknik Purposive Sampling. Alat ukur menggunakan kuesioner. Tingkat pengetahuan orang tua tentang rokok pada orang tua yang memiliki anak perokok usia 10-15 tahun pada 38 responden penelitian menunjukkan bahwa tingkat pengetahuan dalam kategori baik. Didapatkan $60,5 \%$ orang tua pada usia 36-45 tahun, $63,2 \%$ orang tua memiliki pendididkan SMA, sebesar 52,6\% orang tua bekerja sebagai IRT, dan $55,4 \%$ orang tua tidak berpenghasilan. Pengetahuan tentang rokok pada orang tua yang memiliki anak perokok usia 10-15 tahun di Dusun Modinan mayoritas dalam kategori pengetahuan baik.
\end{abstract}

Kata Kunci : Pengetahuan, Orang tua, Rokok 


\section{Pendahuluan}

Orang tua merupakan sosok figure bagi anak dan tempat dimana anak dapat berbagai pendapat. Semua yang akan dilakukan orang tua pasti anak akan meniru perilaku tersebut, contoh merokok meski tanda larangan merokok sudah dipasang di berbagai area publik, tetapi masih banyak perokok yang mengabaikan. Padahal disekitar mereka tak hanya orang dewasa, melainkan juga anak-anak. ${ }^{1}$

Merokok merupakan perilaku yang berbahaya bagi kesehatan, telah banyak orang mengetahui dampak bahaya dari merokok, tetapi masih saja jumlah perokok bahkan semakin hari terus meningkat. Setiap orang baik yang tinggal di wilayah kota maupun desa pada umumnya sudah tidak tabu dengan perilaku merokok. Sudah ditemukan bahwa tidak hanya laki-laki dewasa, akan tetapi perempuan, anak muda, orang tua bahkan anak kecilpun sudah banyak melakukan perilaku merokok karena untuk saat ini usia merokok semakin hari semakin bertambah muda. Perilaku merokok dilihat dari berbagai sudut pandang sangat merugikan, baik perokok atau orang yang berada di sekeliling perokok. Perilaku merokok juga menimbulkan dampak negatif bagi perokok pasif, bahkan risiko dari zat-zat yang ada pada rokok sangat berbahaya untuk perokok pasif. ${ }^{2}$

Anak adalah aset yang dimiliki bangsa dan sebagai generasi penerus citacita perjuangan bangsa yang akan menentukan masa depan bangsa dan negara kita. Oleh karena itu, perhatian dan harapan yang besar perlu diberikan kepada anak. Apabila anak tidak di didik dengan benar akan berpengaruh untuk kedepannya seperti melakukaan perilaku merokok, karena perkembangan yang ada di Indonesia di dapatkan masalah anak merokok. ${ }^{3}$

Menurut World Health Organization (WHO), tembakau membunuh lebih dari 5 juta orang pertahun dan diprediksi akan membunuh 10 juta orang sampai tahun 2020, dari jumlah itu $70 \%$ korban berasal dari negara berkembang didominasi oleh kaum laki-laki sebesar 700 juta terutama di Asia. WHO memperkirakan 1,1 miliar orang merokok didunia berumur 15 tahun ke atas yaitu sepertiga dari total penduduk dunia. Indonesia menduduki peringkat ke-3 dalam konsumsi rokok di dunia setelah China dan India.4 
Berdasarkan Kemenkes tahun 2013, Di Indonesia sebesar 85\% rumah tangga terpapar asap rokok, artinya adalah 8 perokok meninggal karena perokok aktif, satu perokok pasif meninggal karena terpapar asap rokok orang lain. Dari masalah diatas maka \pm 25.000 kematian di Indonesia dikarenakan asap rokok orang lain. Pada tahun 2010 diketahui bahwa prevalensi perokok di Indonesia sebesar 34,2\% dan semakin meningkat pada tahun 2013 menjadi 36,3\%. Untuk konsumsi rokok pada setiap harinya per orang di Indonesia pada tahun 2013 sebanyak 12,3 batang per hari (setara satu bungkus). Indonesia mengalami peningkatan terbesar perilaku merokok yang cenderung dimulai pada usia yang semakin muda. Pada usia 5-9 tahun terdapat 1,6\% usia 10-14 tahun, terdapat 18\% remaja yang merokok, dari usia diatas tidak hanya laki-laki saja bahkan perempuan dengan usia yang sama sudah mulai merokok. ${ }^{4}$

Yogyakarta merupakan provinsi dengan prevalensi umur $\geq 10$ tahun yang tiap hari merokok sebanyak $21,2 \%$. Ada banyak alasan para remaja atau anak usia $\leq 15$ tahun berperilaku merokok. Faktor-faktor yang mengakibatkan anak merokok adalah faktor dari lingkungan yaitu apabila orang tua merokok maka anak akan mencontoh perilaku orang tua tersebut atau teman sebayanya dan faktor dari individu sendiri. Kejadian merokok pada anak usia $\leq 15$ tahun umumnya ditemukan di daerah perkotaan, akan tetapi semakin berjalannya waktu anak merokok ditemukan diwilayah perdesaan. ${ }^{4}$

Perubahan perilaku seseorang memiliki tahap proses perubahan dari pengetahuan menjadi perilaku, terdapat hubungannya antara tingkat pengetahuan dengan faktor perilaku sebagai contoh perilaku merokok. Pengetahuan tentang merokok merupakan faktor yang mempegaruhi perilaku merokok, dimana faktorfaktor tersebut dapat dipengaruhi dari orang tua berupa faktor usia, pekerjaan, pendidikan serta penghasilan orang tua. ${ }^{5}$

Kabupaten Sleman yang memiliki banyak perokok aktif. Berdasarkan studi pendahuluan pada minggu 11 Desember 2016 diperoleh data di Dusun Modinan Banyuraden Gamping Sleman bahwa terdapat 3 RW dan 14 RT. Ada beberapa warga Modinan yang merupakan bukan warga asli. Sebagian besar perokok aktif usia dewasa perempuan maupun laki-laki, usia remaja dan anak-anakpun sudah 
melakukan perilaku merokok. Di setiap rumah hampir terdapat salah satu anggota keluarga yang menjadi perokok aktif. Dampak dari anak merokok sendiri akan berpengaruh terhadap pergaulan anak tersebut mulai dari sering nongkrong dengan teman sebaya pada saat jam belajar maupun perilaku membolos.

Hasil observasi dari 10 keluarga di Dusun Modinan terdapat 8 keluarga dengan orang tua sebagai perokok aktif. Berdasarkan hasil survey dari fenomena diatas, dari jumlah anak yang berusia 10-15 tahun di Dusun Modinan Banyuraden Gamping Sleman anak sudah merokok. Mereka merokok kebanyakan ikut-ikutan dan terpengaruh oleh teman sebayanya yang beranggapan bahwa merokok akan terlihat lebih dewasa ataupun jantan. Masalah ini mengakibatkan anak yang berusia 10-15 tahun tertarik untuk merokok. Terdapat alasan lain, rokok mudah untuk dibeli dijual dengan harga eceran dengan harga \pm Rp. 2000,00 membuat anak-anak mudah mendapatkannya. Anak merokok menjauh dari lingkungan rumah agar orang tua mereka tidak mengetahui bahwa anaknya merokok.

Masalah mengenai anak merokok diperlukan solusi dan berbagai langkah antisipasi, seperti lebih memantau setiap perilaku yang dilakukan anak. Solusi yang lain adalah dengan mengukur pengetahuan orang tua sebagaimana yang akan peneliti lakukan dengan penelitian berjudul "Gambaran Pengetahuan Tentang Merokok Pada Orang Tua Yang Memiliki Anak Perokok Usia 10-15 Tahun Di Dusun Modinan Banyuraden Gamping Sleman”.

\section{Metode Penelitian}

Penelitian ini merupakan penelitian deskriptif dengan desain survei. Sampel penelitian ini diambil menggunakan teknik Purposive Sampling. Populasi dalam penelitian ini adalah orang tua yang memiliki anak perokok usia 10-15 tahun di Dusun Modinan Banyuraden Gamping Sleman yaitu sebanyak 60 anak. Jumlah sampel sebanyak 38 responden. Penelitian dilaksananakan di Dusun Modinan Banyuraden Gamping Sleman pada tanggal 5 Maret- 27 April 2017. Dalam penelitian ini menggunakan variabel tunggal yaitu pengetahuan tentang merokok pada orangtua yang memiliki anak perokok usia 10-15 tahun Di Dusun Modinan Banyuraden Gamping. Instrumen penelitian menggunakan kuesioner. 
Hasil

Tabel 3 Distribusi Frekuensi Karakteristik Responden Berdasarkan Usia, Pendidikan, Pekerjaan, dan Penghasilan Di Dusun Modinan Tahun 2017 $(n=38)$

\begin{tabular}{lcc}
\hline \multicolumn{1}{c}{ Katagori } & Frekuensi (F) & Persentase(\%) \\
\hline 1. Usia & 1 & 2,6 \\
a. 17-25 Tahun & 4 & 10,5 \\
b. 26-35 Tahun & 23 & 60,5 \\
c. 36-45 Tahun & 9 & 23,8 \\
d. 46-55 Tahun & 1 & 2,6 \\
e. 56-65 Tahun & 38 & 100 \\
\hline Jumlah & & \\
\hline 2. Pendidikan & 0 & 0 \\
a. Tidak Sekolah & 3 & 7,9 \\
b. SD & 10 & 26,3 \\
c. SMP & 24 & 63,2 \\
d. SMA & 1 & 2,6 \\
e. PT & 38 & 100 \\
\hline Jumlah & 21 & 55,3 \\
\hline 3. Pekerjaan & 0 & 0 \\
a. IRT & 3 & 7,9 \\
b. Petani & 2 & 5,2 \\
c. Buruh & 12 & 31,6 \\
d. PNS/TNI/POLRI & 38 & 100 \\
e. Wiraswasta & 1 & 2,6 \\
\hline Jumlah & 25 & 65,8 \\
\hline 4. Penghasilan & 12 & 31,6 \\
a. \&1.000.000 & 38 & 100 \\
b. 1.000.000- & & \\
c. 3.000.000 & & \\
\hline Jumlah & & \\
\hline
\end{tabular}

Tabel 3 dapat diketahui bahwa umur responden sebagian besar berusia 36-45 tahun dengan 23 responden (60,5\%), tingkat pendidikan responden sebagaian besar tamat SMA dengan 24 responden $(63,2 \%)$, mayoritas pekerjaan responden adalah sebagai IRT dengan 21 responden $(55,3 \%)$ jumlah penghasil paling banyak dengan 1-3 juta sebanyak 25 responden $(65,8 \%)$. 
Tabel 4 Distribusi Frekuensi Pengetahuan Tentang Merokok Pada Orang Tua Yang Memiliki Anak Perokok Berdasarkan Usia Di Dusun Modinan Tahun $2017(\mathrm{n}=38)$

\begin{tabular}{clcc}
\hline No & Tingkat Pengetahuan & Frekuensi(F) & Persentase (\%) \\
\hline 1. & Baik & 22 & 58 \\
\hline 2. & Cukup & 14 & 36,8 \\
\hline 3. & Kurang & 2 & 5,2 \\
\hline & Jumlah & 38 & 100 \\
\hline
\end{tabular}

Tabel 4 diketahui bahwa jumlah responden paling banyak memiliki pengetahuan baik yaitu sebanyak 22 Responden (58\%).

Tabel 5 Distribusi Pengetahuan Tentang Merokok Pada Orang Tua Yang Memiliki Anak Perokok Berdasarkan Usia Di Dusun Modinan Tahun $2017(\mathrm{n}=38)$

\begin{tabular}{|c|c|c|c|c|c|c|c|c|c|}
\hline \multirow[t]{3}{*}{ No } & \multirow{3}{*}{$\begin{array}{c}\text { Usia } \\
\text { (Tahun) }\end{array}$} & \multicolumn{6}{|c|}{ Pengetahuan } & \multirow[t]{3}{*}{$\mathrm{N}$} & \multirow[t]{3}{*}{$\%$} \\
\hline & & \multicolumn{2}{|c|}{ Baik } & \multicolumn{2}{|c|}{ Cukup } & \multicolumn{2}{|c|}{ Kurang } & & \\
\hline & & $F$ & $\%$ & F & $\%$ & $F$ & $\%$ & & \\
\hline 1. & $17-25$ & 1 & 2,6 & 0 & 0 & 0 & 0 & 1 & 2,6 \\
\hline 2. & $26-35$ & 3 & 7,9 & 1 & 2,6 & 0 & 0 & 4 & 10,5 \\
\hline 3. & $36-45$ & 13 & 34,2 & 8 & 21 & 2 & 5,2 & 23 & 60,5 \\
\hline 4. & $46-55$ & 5 & 13,3 & 4 & 10,5 & 0 & 0 & 9 & 23,8 \\
\hline 5. & $56-65$ & 0 & 0 & 1 & 2,6 & 0 & 0 & 1 & 2,6 \\
\hline
\end{tabular}

Tabel 5 diketahui bahwa responden yang memiliki pengetahuan baik tentang rokok paling banyak pada usia 36-45 tahun yaitu sebesar 13 responden (34,2\%).

Tabel 6 Distribusi Pengetahuan Tentang Merokok Pada Orang Tua Yang Memiliki Anak Perokok Berdasarkan Pendidikan Di Dusun Modinan Tahun $2017(\mathrm{n}=38)$

\begin{tabular}{|c|c|c|c|c|c|c|c|c|c|}
\hline \multirow[t]{3}{*}{ No } & \multirow[t]{3}{*}{ Pendidikan } & \multicolumn{6}{|c|}{ Pengetahuan } & \multirow[t]{3}{*}{$\mathrm{N}$} & \multirow[t]{3}{*}{$\%$} \\
\hline & & \multicolumn{2}{|c|}{ Baik } & \multicolumn{2}{|c|}{ Cukup } & \multicolumn{2}{|c|}{ Kurang } & & \\
\hline & & $\mathrm{F}$ & $\%$ & $\mathrm{~F}$ & $\%$ & $\mathrm{~F}$ & $\%$ & & \\
\hline 1. & $\begin{array}{c}\text { Tidak } \\
\text { Sekolah }\end{array}$ & 0 & 0 & 0 & 0 & 0 & 0 & 0 & 0 \\
\hline 2. & $\mathrm{SD}$ & 2 & 5,3 & 1 & 2,6 & 0 & 0 & 3 & 7,9 \\
\hline 3. & SMP & 5 & 13,1 & 3 & 7,9 & 2 & 5,3 & 10 & 26,3 \\
\hline 4. & SMA & 14 & 36,9 & 10 & 26,3 & 0 & 0 & 24 & 63,2 \\
\hline 5. & PT & 1 & 2,6 & 0 & 0 & 0 & 0 & 1 & 2,6 \\
\hline
\end{tabular}

Tabel 6 diketahui bahwa responden yang memiliki pengetahuan baik tentang rokok paling banyak dengan pendidikan terakhir SMA yaitu sebesar 14 responden $(36,9 \%)$. 
Tabel 7 Distribusi Pengetahuan Tentang Merokok Pada Orang Tua Yang Memiliki Anak Perokok Berdasarkan Pekerjaan Di Dusun Modinan Tahun $2017(\mathrm{n}=38)$

\begin{tabular}{|c|c|c|c|c|c|c|c|c|c|}
\hline \multirow[t]{3}{*}{ No } & \multirow[t]{3}{*}{ Pekerjaan } & \multicolumn{6}{|c|}{ Pengetahuan } & \multirow[t]{3}{*}{$\mathrm{N}$} & \multirow[t]{3}{*}{$\%$} \\
\hline & & \multicolumn{2}{|c|}{ Baik } & \multicolumn{2}{|c|}{ Cukup } & \multicolumn{2}{|c|}{ Kurang } & & \\
\hline & & $\mathrm{F}$ & $\%$ & $\mathrm{~F}$ & $\%$ & $\mathrm{~F}$ & $\%$ & & \\
\hline 1. & IRT & 11 & 28,9 & 9 & 23,7 & 1 & 2,6 & 21 & 55,2 \\
\hline 2. & Petani & 0 & 0 & 0 & 0 & 0 & 0 & 0 & 0 \\
\hline 3. & Buruh & 1 & 2,6 & 1 & 2,6 & 1 & 2,6 & 3 & 7,9 \\
\hline 4. & PNS/TNI/POLRI & 1 & 2,6 & 1 & 2,6 & 0 & 0 & 2 & 5,2 \\
\hline 5. & Wiraswasta & 9 & 23,8 & 3 & 7,9 & 0 & 0 & 12 & 31,7 \\
\hline
\end{tabular}

Tabel 7 diketahui bahwa responden yang memiliki pengetahuan baik tentang rokok paling banyak pada orang tua sebagai Ibu Rumah Tangga yaitu sebesar 11 responden $(28,9 \%)$.

Tabel 8 Distribusi Pengetahuan Tentang Merokok Pada Orang Tua Yang Memiliki Anak Perokok Berdasarkan Penghasilan Di Dusun Modinan Tahun $2017(\mathrm{n}=38)$

\begin{tabular}{|c|c|c|c|c|c|c|c|c|c|}
\hline \multirow[t]{3}{*}{ No } & \multirow{3}{*}{ Penghasilan } & \multicolumn{6}{|c|}{ Pengetahuan } & \multirow[t]{3}{*}{$\mathrm{N}$} & \multirow[t]{3}{*}{$\%$} \\
\hline & & \multicolumn{2}{|c|}{ Baik } & \multicolumn{2}{|c|}{ Cukup } & \multicolumn{2}{|c|}{ Kurang } & & \\
\hline & & $\mathrm{F}$ & $\%$ & $\mathrm{~F}$ & $\%$ & F & $\%$ & & \\
\hline 1. & $<1.000 .000$ & 0 & 0 & 1 & 2,6 & 0 & 0 & 1 & 2,6 \\
\hline 2. & $\begin{array}{l}1.000 .000- \\
3.000 .000\end{array}$ & 13 & 34,4 & 10 & 26,3 & 2 & 5,2 & 25 & 65,9 \\
\hline 3. & $>3.000 .000$ & 10 & 26,3 & 2 & 5,2 & 0 & 0 & 12 & 31,5 \\
\hline
\end{tabular}

Tabel 8 diketahui bahwa responden yang memiliki pengetahuan baik tentang rokok paling banyak pada orang tua yang tidak memiliki penghasilan 1.000.0003.000 .000 yaitu sebesar 13 responden $(34,4 \%)$.

\section{Pembahasan}

Berdasarkan data diketahui bahwa pengetahuan responden tentang merokok di Dusun Modinan paling banyak dalam kategori baik sebanyak 22 responden. Hal ini sesuai dengan hasil penelitian mengatakan bahwa pengetahuan tentang rokok saat ini bisa dipelajari dan didapatkan dari berbagai hal.6

Hal ini sejalan dengan teori yang mengatakan bahwa Tahu diartikan hanya sebagai mengingat kembali (recall) terhadap rangsangan yang diterima. Tahu dapat diartikan mengingat materi yang pernah disampaikan.7 
Hal ini sejalan dengan teori yang mengatakan bahwa Pengetahuan merupakan hasil dari tahu merupakan faktor-faktor dominan yang penting dalam membentuk tindakan seseorang (overt behaviour). Proses kognitif meliputi ingatan, pikiran, persepsi, simbol-simbol, penalaran dan pemecahan masalah. ${ }^{8}$

Dari total 38 terdapat responden berpengetahuan kurang yaitu 2 responden dan berpengetahuan cukup 14 responden. Hal ini sesuai dengan hasil penelitian yang mengatakan bahwa masih terdapat responden pada penelitian pada kategori cukup dan kurang. Hal ini bisa dikarenakan responden kurang menggunakan manfaat sumber informasi yang ada. ${ }^{9}$

Pengetahuan orang tua (ibu) tentang merokok pada orang tua yang memiliki anak perokok usia 10-15 tahun berdasarkan usia. Distribusi responden menurut usia sebagaian besar responden berusia 36-45 tahun, usia tersebut termasuk dalam kategori dewasa akhir.10 Hal ini didukung dengan hasil penelitian bahwa penggolongan usia 30-45 tahun termasuk pada masa dewasa akhir, maka dari itu orang tua dengan rentang usia menunjukkan tingkat pengetahuan yang baik yaitu dalam rentang usia 25-45 tahun. ${ }^{11}$

Rentang usia 36-45 tahun terdapat 13 responden pada kategori pengetahuan baik dan 8 responden dalam kategori cukup. Hal ini sesuai dengan teori yang mengatakan bahwa usia memengaruhi daya tangkap dan pola pikir seseorang. Sehingga semakin bertambah usia semakin berkembang pula daya tangkap dan pola pikir mempengaruhi pengetahuan diperolehnya membaik. Semakin tua semakin bijaksana, semakin banyak informasi yang dijumpai dan semakin banyak dikerjakan sehingga menambah pengetahuan. ${ }^{12}$

Mayoritas responden termasuk pada kategori dewasa jadi semakin bertambah usia kematangan seseorang baik dalam berfikir atau bertindak serta bertambahnya usia informasi yang didapat lebih banyak berpengaruh terhadap pengetahuan, pengetahuan responden mengenai rokok menjadi lebih baik.

Pengetahuan orang tua (ibu) tentang merokok pada orang tua yang memiliki anak perokok usia 10-15 tahun berdasarkan pendidikan. Distribusi berdasarkan pendidikan sebagaian besar adalah tamat SMA. Hasil penelitian ini didukung dengan penelitian sebagian responden berpendidikan akhir SMA yaitu 
66\%. Tingkat pendidikan yang diselesaikan responden lebih berkaitan dengan pilihan hidup dari responden. ${ }^{13}$

Hal ini juga sesuai dengan teori bahwa tingkat Pendidikan dapat menjadi upaya yang memberikan pengetahuan sehingga perubahan perilaku positif yang meningkat. Pendidikan diperlukan mendapatkan informasi misalnya hal-hal yang menunjang kesehatan sehingga meningkatkan kualitas hidup. ${ }^{5}$

Pendidikan dapat menggambarkan mengenai kemampuan seseorang dalam memperoleh dan memahami informasi. Semakin tinggi pendidikan yang dimiliki semakin baik pula tingkat pemahaman yang didapat. Didapatkan 1 responden dengan pendidikan akhir perguruan tinggi termasuk pada kategori pengetahuan baik dan 24 responden yang berpendidikan akhir SMA termasuk pada kategori baik dan cukup. Hal ini sesuai dengan teori mengatakan bahwa pendidikan adalah sebuah proses pengubahan sikap dan tata laku seseorang atau kelompok dan juga usaha mendewasakan manusia melalui upaya pengajaran dan pelatihan. Pendidikan mempengaruhi proses belajar, semakin tinggi pendidikan seseorang, maka mudah bagi orang terssebut untuk menerima informasi. ${ }^{12}$

Hal ini didukung dari hasil penelitian mengatakan bahwa kebiasaan merokok pada anak memang tidak lepas dari pendidikan orang tua yaitu berpengaruh terhadap pola asuh pada anak dirumah. Pendidikan orang tua yang semakin tinggi semakin baik pula pengetahuan yang dimiliki dan dapat memberikan penjelasan terhadap anak perbuatan baik maupun buruk. ${ }^{14}$

Pengetahuan orang tua (ibu) tentang merokok pada orang tua yang memiliki anak perokok usia 10-15 tahun berdasarkan pekerjaan. Distribusi berdasarkan pekerjaan sebagian besar adalah sebagai IRT. Hal ini dapat menunjukkan terjadi interaksi ibu dengan anak yang lebih sering.

Responden sebagian besar adalah ibu rumah tangga jadi lebih banyak mendapatkan informasi mengenai rokok. Dari data pada tabel 4 bahwa terdapat 13 reponden sebagai IRT termasuk pada kategori baik dan 1 responden yang bekerja sebagai buruh berpengetahuan kurang. Hal ini sejalan dengan penelitian dilakukan yang menyebutkan bahwa Ibu Rumah Tangga memiliki pengetahuan baik tentang 
bahaya merokok dikarenakan banyak Ibu Rumah Tangga dapat memperoleh informasi tentang rokok dari televisi, internet ataupun surat kabar. ${ }^{6}$

Selain itu, pekerjaan juga dapat menunjukkan tingkat sosial ekonomi seseorang nantinya akan berpengaruh pada tingkat pengetahuan, misalkan pada keluarga yang memiliki status ekonomi menengah ke atas akan mudah untuk mencari informasi yang dibutuhkan dalam merawat anaknya, selain itu keluarga akan dengan mudah menyekolahkan anaknya di sekolah-sekolah yang baik, orang tua mendapatkan cara-cara bagaimana merawat anaknya dengan baik. Hal ini sesuai dengan teori bahwa keburukan yang harus dilakukan terutama untuk menunjang kehidupannya. ${ }^{5}$

Tingkat pengetahuan ibu rumah tangga lebih tinggi dibandingkan dengan yang bekerja karena informasi yang didapatkan oleh ibu rumah tangga lebih banyak dari pada ibu yang bekerja, ibu rumah tangga memiliki banyak waktu untuk memperoleh informasi dari televisi, internet ataupun surat kabar. Hal ini Sesuai dengan teori menyatakan bahwa informasi merupakan suatu yang dapat diketahui atau sebagai kemudahan untuk memperoleh informasi mempercepat seseorang mendapatkan pengetahuan yang baru. ${ }^{15}$

Pengetahuan orang tua (ibu) tentang merokok pada orang tua yang memiliki anak perokok usia 10-15 tahun berdasarkan penghasilan didapatkan bahwa mayoritas responden berpenghasilan 1-3 juta yaitu sebanyak 25 responden. 25 responden berpenghasilan 1-3 juta terdapat 13 responden yang berpengetahuan baik, namun terdapat 2 responden yang pengetahuannya kurang. Dari kesenjangan tersebut bisa jadi karena faktor ekonomi menengah kebawah mengakibatkan ibu tidak dapat mengakses informasi. Hasil ini tidak sesuai dengan teori Tingkat kemampuan memenuhi kebutuhan hidup seseorang yang mempunyai sumber informasi yang lebih banyak, akan memberikan pengaruh pengetahuan lebih jelas. ${ }^{5}$ Dari hasil penelitian tersebut sejalan dengan teori yang mengatakan bahwa status ekonomi seseorang menentukan tersedianya fasilitas diperlukan untuk kegiatan tertentu sehingga status sosial ekonomi mempengaruhi pengetahuan seseorang. ${ }^{12}$ Dari hasil penelitan tersebut sesuai dengan hasil penelitian yang mengatakan bahwa orang tua yang berpendapatan tinggi empat 
kali kemungkinan memiliki pengetahuan baik dari pada orang tua berpendapatan rendah. ${ }^{16}$ 


\section{Kesimpulan}

Hasil penelitian yang telah dilakukan di Dusun Modinan dengan jumlah responden 38 orang, maka peneliti mengambil kesimpulan bahwa gambaran pengetahuan tentang merokok pada orang tua yang memiliki anak perokok usia 10-15 tahun di Dusun Modinan Banyuraden Gamping Sleman Tahun 2017 dalam kategori baik, secara rinci adalah orang tua yang memiliki pengetahuan tentang rokok pada anak yang berusia 10-15 tahun di Dusun Modinan dalam kategori baik mayoritas berusia 36-45 tahun. Orang tua yang memiliki pengetahuan tentang rokok pada anak yang berusia 10-15 tahun di Dusun Modinan dalam kategori baik mayoritas berpendidikan akhir SMA. Orang tua yang memiliki pengetahuan tentang rokok pada anak yang berusia 10-15 tahun di Dusun Modinan dalam kategori baik mayoritas bekerja sebagai IRT (Ibu Rumah Tangga). Orang tua yang memiliki pengetahuan tentang rokok pada anak yang berusia 10-15 tahun di Dusun Modinan dalam kategori baik mayoritas pada penghasilan 1-3 juta.

\section{Saran}

Warga Dusun Modinan diharapkan orang tua dapat lebih memantau anaknya. Serta dapat mendampingi setiap kegiatan anaknya sehingga tidak ada anak usia 10-15 tahun yang merokok. Peneliti berikutnya yang akan melakukan penelitian yang sama, dapat menambahkan kategori orang tua ayah kandung atau sambung sebagai responden dalam penelitian. Peneliti berikutnya yang akan melakukan penelitian yang sama, dapat dijadikan sebagai data dasar untuk penelitian lebih lanjut dengan metode korelasional atau studi kasus dan ketepatan pada pengambilan kesimpulan.

\section{DAFTAR PUSTAKA}

1. Faizi, M. (2012). Mendidik Anak ala Pendidikan Orang Hebat. Yogyakarta: Flashbooks.

2. Tarwoto, Ns. Dkk. (2010). Kesehatan Remaja problem dan solusinya. Jakarta: Salemba Medika.

3. Kemenkes. (2014). Riset Kesehatan Dasar. Jakarta: Badan Penelitian dan pengembangan Kesehatan Kementrian Kesehatan RI.

4. Riskesdas. (2013). Riset Kesehatan Dasar 2013. Jakarta: Badan Penelitian dan Pengembangan. 
5. Notoadmojo, S. (2007). Metodologi Penelitian Kesehatan. Jakarta: Rinek Cipta.

6. Syarfa, I. (2015). Skripsi. Gambaran Tingkat Pengetahuan, Perilaku Merokok Dan Nikotin Dependen Mahasiswa Uin Syarif Hidayatullah Jakarta. Fakultas Kedokteran Dan Ilmu Kesehatan Universitas Islam Negeri Syarif Hidayatullah Jakarta.

7. Wawan, A dan Dewi, M. (2010). Pengetahuan Sikap dan Perilaku Manusia. Yogyakarta: Nuha Medika.

8. Lestari, T. (2014). Kumpulan Teori Untuk Kajian Pustaka Penelitian Kesehatan. Yogyakarta: Nuha Medika

9. Yosantaraputra, dkk. (2014). Skripsi. Gambaran Pengetahuan dan Sikap Mahasiswa Fakultas Kedokteran Universitas Andalas tentang Rokok. Fakultas Kedokteran Universitas Andalas. Diunduh pada tanggal 28 Desember 2016.

10. Depkes RI. 2009. Sistem Kesehatan Nasional. Jakarta.

11. Durant, dkk (2015). Skripsi. Hubungan Antara Pola Asuh Orang Tua Dengan Kebiasaan Merokok Anak Usia Remaja 12-17 Tahun Di Desa Kilometer Tiga Kecamatan Amurang. Ejournal Keperawatan (e-Kep) Volume 3 Nomor 1. Diunduh pada tanggal 16 Juni 2017.

12. Budiman \& Agus R. (2013). Kapita Selekta Kuesioner Pengetahuan Dan Sikap Dalam Penelitian Kesehatan. Jakarta : Salemba Medika.

13. Novicka, Erine Vila. (2012). Skripsi. Hubungan Pola Asuh Orangtua Dengan Perilaku Merokok Pada Remaja Laki-laki Cendono Kecamatan Dawe Kabupaten Kudus. Fakultas Keperawatan dan Kesehatan Universitas Muhammadiyah Semarang. Diunduh pada 16 Juni 2017.

14. Wahyudi. (2015). Skripsi. Hubungan Orang Tua Perokok Dengan Kebiasaan Merokok Pada Anak Usia 15-18 Tahun Di Desa Majasto Tawangsari Sukoharjo. Keperawatan Stikes Kusuma Husada Surakarta. Diunduh pada tanggal 16 Juni 2017

15. Mubarak. (2012). Ilmu Kesehatan Masyarakat Konsep Dan Aplikasi Dalam Kebidanan. Jakarta : Salemba Medika

16. Kerley. (2015). Skripsi. Hubungan Karakteristik Orang Tua Dengan Pengetahuan Orang Tua Tentang Kekerasan Seksual Pada Anak Usia Prasekolah 3-5 Tahun Di Kelurahan Grogol Selatan Kebayoran Lama Jakarta Selatan. Fakultas kedokteran dan ilmu kesehatan Jakarta. Diunduh pada tanggal 16 juni 2017. 